\title{
Influence of Dates of Sowing on Incidence of Mungbean Yellow Mosaic Virus (MYMV) in Mungbean
}

\author{
Meghashree Meti* and Mallikarjun Kenganal
}

Department of Plant Pathology, College of Agriculture, Raichur and Main Agriculture

Research Station, University of Agricultural Sciences, Raichur 584104, Karnataka, India

*Corresponding author

\section{A B S T R A C T}

Mungbean is one of the most desired legume of vegetarians, its wide cultivation across many parts of Africa, South East Asia including India is driven by its huge demand across many parts of the world. However, its cultivation is suffering in all these regions due to Yellow Mosaic Disease (YMD) caused by Mungbean yellow mosaic virus (MYMV). Hence present investigation was carried out to understand the effect of date of sowing on

\section{Keywords}

Mungbean, MYMV, Kharif and Standard meteorological week

\section{Article Info}

Accepted: 16 August 2018 Available Online: 10 September 2018 incidence of MYMV in mungbean during Kharif 2016-17. Mungbean was sown at weekly interval of Standard Meteorological Week (SMW) starting from $22^{\text {nd }}$ SMW up to 7 weeks. First sowing was done on $30^{\text {th }}$ May $\left(22^{\text {nd }}\right.$ SMW), followed by $6^{\text {th }}$ June $\left(23^{\text {rd }}\right.$ SMW $), 13^{\text {th }}$ June $\left(24^{\text {th }} \mathrm{SMW}\right), 20^{\text {th }}$ June $\left(25^{\text {th }}\right.$ SMW $), 4^{\text {th }}$ July $\left(27^{\text {th }}\right.$ SMW) and last was on $11^{\text {th }}$ July ( $28^{\text {th }}$ SMW). Observations on incidence of MYMV at each date of sowing and yield parameters recorded were subjected to statistical analysis. The results of revealed that, most suitable date of sowing with maximum yield parameters was $23^{\text {rd }}$ SMW (6 ${ }^{\text {rd }}$ June) which recorded least MYMV incidence of 4.85 per cent with highest of 9.32 pods/plant and seed yield of $1220 \mathrm{~kg} \mathrm{ha}^{-1}$, followed by $22^{\text {nd }}$ SMW ( $30^{\text {th }}$ May) sowing which recorded disease incidence of 6.84 per cent with 8.92 pods/plant and seed yield of $1093 \mathrm{~kg} \mathrm{ha}^{-1}$. The lowest yield parameters of 6 pods/plant and $112 \mathrm{~kg} \mathrm{ha}^{-1}$ seed yield was recorded in the plot sown on $28^{\text {th }}$ SMW (1 $1^{\text {th }}$ July) with highest MYMV incidence of 15.15 per cent followed by $27^{\text {th }} \mathrm{SMW}\left(4^{\text {th }}\right.$ July) sown plot, which recorded on par of 6.2 pods/plant and $116 \mathrm{~kg} \mathrm{ha}^{-1}$ seed yield with incidence of 13.60 per cent. Hence from each date of sowing reveals the most suitable date of sowing for mungbean is $6^{\text {th }}$ June $\left(23^{\text {rd }}\right.$ SMW), which had lowest MYMV incidence and highest seed yield compared to others.

\section{Introduction}

Mungbean [Vigna radiata (L.) Wilczek] also known as greengram. The crop is native to the Indian subcontinent and cultivated in other South East Asian countries such as Pakistan, Bangladesh, Sri Lanka, Philippines, Taiwan, Nepal, Thailand, Laos, Kampuchea, Vietnam,
Indonesia, Eastern Malaysia, Southern China and Java (Singh, 1991). Mungbean is grown principally for its protein rich edible seeds which are used for consumption by cooking, fermenting, milling or sprouting. Seeds are also used for making soups, curries, bread, sweets, noodles, salads, papad etc. (Singh et al., 1988). It is one of the major sources of 
protein, it contains isoflavanoids having estrogen and antioxidant activities useful in prevention of diseases such as cancer, it also exhibits antimicrobial and insecticidal activities (Sheteawi and Tawfit, 2007). Being a leguminous crop, it plays an important role in improving the soil fertility through biological nitrogen fixation (Asghar et al., 2006), checks soil erosion as a cover crop, used as a green manure and fodder crop as well (Sahay et al., 1999). Among many biotic stresses mungbean yellow mosaic disease caused by Mungbean Yellow Mosaic Virus (MYMV) is considered as a number one threat of mungbean, limiting the production and productivity. The virus is most destructive in Indian subcontinent and adjacent areas of South-East Asia causing 100 per cent yield losses. It causes severe disease and economic losses in mungbean by plummeting seed yield and quality (Kang et al., 2005). Mungbean yellow mosaic virus belongs to the family Geminiviridae and genus begomovirus consisting of viruses with circular $(20 \times 30$ $\mathrm{nm}$ ), single-stranded (ss) DNA genome (Hull, 2004). Transmitted by whitefly (Bemisia tabaci) (Borah and Dasgupta, 2012). As mungbean is mainly grown in kharif, the present investigation focused on finding out suitable date of sowing to escape / avoid the incidence of MYMV in kharif.

\section{Materials and Methods}

This study was conducted during kharif 2016. Mungbean was sown at weekly interval starting from $22^{\text {nd }}$ standard week (last week of may $/ 1^{\text {st }}$ week of June) up to 7 weeks. For each date of sowing, $5 \times 3 \mathrm{~m}$ plot was sown in three replications using Randomized Complete Block Design (RCBD). Normal agronomic practices, cultural operations and recommended package of practices were followed for all dates of sowing (treatments) till harvest. The observation on incidence of MYMV was recorded after the first appearance of symptoms and at weekly intervals subsequently. Yield parameters like pods per plant, and seed yield were recorded at harvesting. The per cent disease incidence was calculated using following formula as mentioned below;

Per cent Disease

Number of plants infected

Incidence $(\mathrm{PDI})=$ $\mathrm{x} 100$

Total number of plants observed

\section{Results and Discussion}

The observations on incidence of MYMV at each date of sowing and yield parameters recorded were subjected to statistical analysis and results revealed that, incidence of yellow mosaic caused by MYMV in mungbean sown at different dates of sowing appeared differently. The progression of disease in all the treatments followed similar trend. However, their final observation of disease incidence varied from 4.85 to 15.15 per cent. The $23^{\text {rd }}$ SMW sowing ( $6^{\text {th }}$ June) recorded lowest incidence of 4.85 per cent MYMV among all the other sowings followed by 6.84 per cent in $22^{\text {nd }}$ SMW sowing $\left(30^{\text {th }}\right.$ May) and 7.67 per cent at $25^{\text {th }}$ SMW sowing $\left(20^{\text {th }}\right.$ June $)$ which was on par with $24^{\text {th }}$ SMW sowing $\left(13^{\text {th }}\right.$ June). The disease incidence had an increasing trend as the date of sowing was extended by each SMW. Highest MYMV incidence of 15.15 per cent was recorded in $28^{\text {th }} \mathrm{SMW}$ sown plot $\left(11^{\text {th }}\right.$ July) followed by 13.60 per cent in $27^{\text {th }}$ SMW sown plot ( $4^{\text {th }}$ July) and 8.45 per cent in $26^{\text {th }}$ SMW sown plot $\left(27^{\text {th }}\right.$ June). Yield parameters recorded had a detrimental effect of dates of sowing, as sowing delayed concurrently the yield declined. The most suitable date of sowing with maximum yield parameters was $23^{\text {rd }}$ SMW ( $6^{\text {rd }}$ June) which recorded the highest of 9.32 pods/plant and seed yield of $1220 \mathrm{~kg} \mathrm{ha}^{-1}$, followed by $22^{\text {nd }}$ SMW (30 ${ }^{\text {th }}$ May) sowing which recorded 8.92 pods/plant and seed yield 
of $1093 \mathrm{~kg} \mathrm{ha}^{-1}$ (Table 1). Yield parameters declined along with increasing trend of disease incidence as the sowing was delayed by weekly intervals (Fig. 1). The lowest yield parameters of 6 pods/plant and $112 \mathrm{~kg} \mathrm{ha}^{-1}$ seed yield was recorded in the plot sown on $28^{\text {th }}$ SMW ( $11^{\text {th }}$ July) followed by $27^{\text {th }}$ SMW $\left(4^{\text {th }}\right.$ July) sown plot, which recorded on par of 6.2 pods/plant and $116 \mathrm{~kg} \mathrm{ha}^{-1}$ seed yield. The final outcome of each date of sowing reveals the most suitable date of sowing for mungbean is $6^{\text {th }}$ June $\left(23^{\text {rd }} \mathrm{SMW}\right)$, which had lowest MYMV incidence and highest seed yield compared to others.

This indicates that mungbean sown on June $6^{\text {th }}$ completes its physiological life cycle (vegetative and reproductive phase) at proper time with lower incidence of MYMV and higher yield. Whereas, decreased disease incidence was due to unfavorable weather conditions like regular showers which interfered with growth and multiplication of whitefly population and hence transmission of MYMV by the vectors was avoided indirectly helped in reducing the total disease incidence.

Our findings were in accordance to a previous study wherein, low incidence of MYMV was observed in early June sown crop compared to July or August sown crops (Rathi and Vijay Veer Singh, 2005). The yield obtained was also higher $\left(1220 \mathrm{~kg} \mathrm{ha}^{-1}\right)$ in $6^{\text {th }}$ June $\left(23^{\text {rd }}\right.$ SMW) sown crop compared to rest of the dates of sowing and lowest $\left(112 \mathrm{~kg} \mathrm{ha}^{-1}\right)$ was in last date of sowing $\left(11^{\text {th }}\right.$ June $\left(28^{\text {th }} \mathrm{SMW}\right)$. The other factors which may add to the yield losses in farmers' field due to delayed sowing are incidence of powdery mildew, anthracnose, bacterial blight and pod fly insect. Their combined effect makes the crop risky among the growers.

Fig.1 Terminal incidence of MYMV and mungbean yield influenced by

\section{Different weeks of sowing}

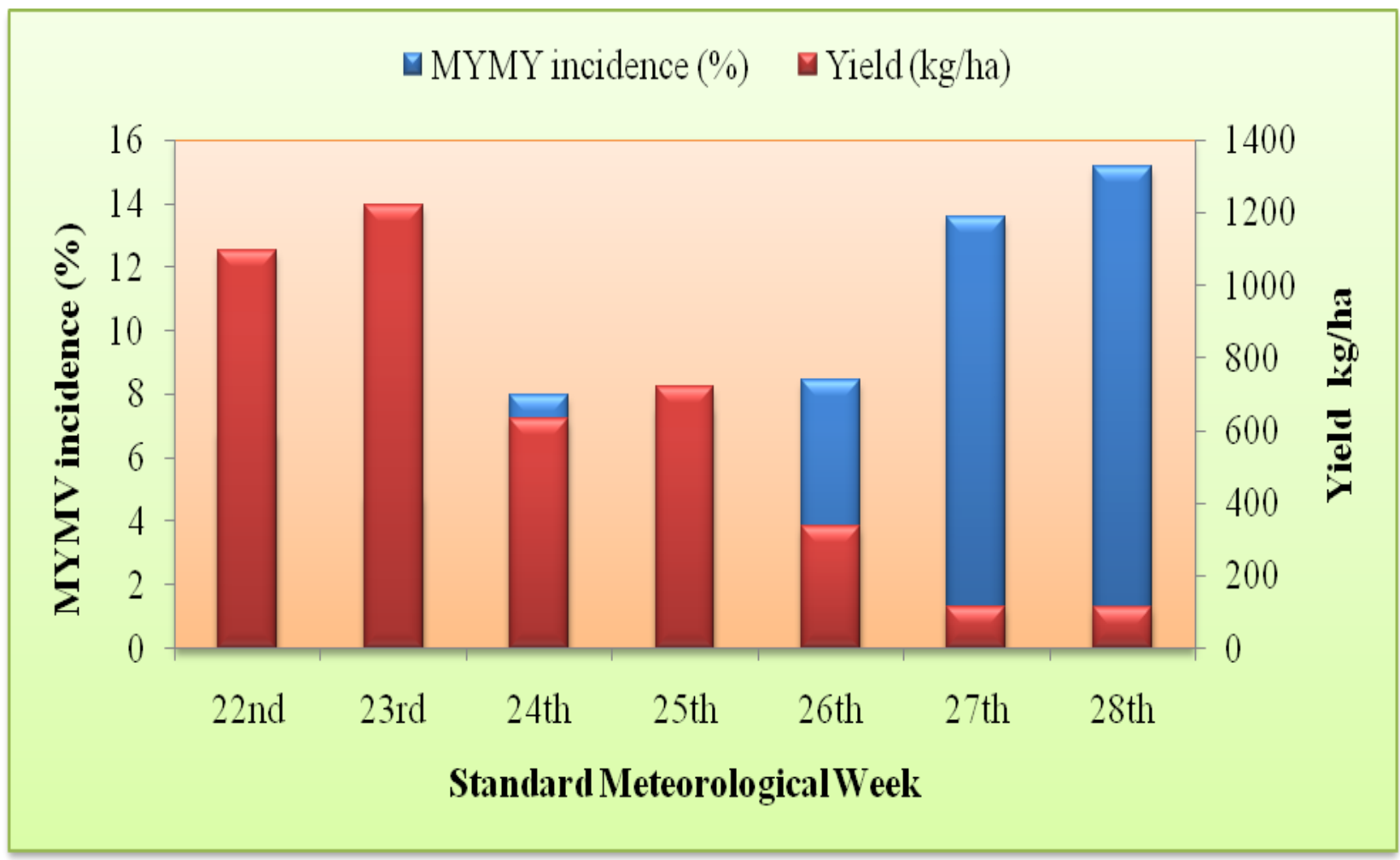


Table.1 Influence date of sowing on incidence of MYMV in mungbean and at its yield parameters during kharif 2016

\begin{tabular}{|c|c|c|c|c|c|c|c|c|c|c|c|}
\hline \multirow[t]{2}{*}{ Treatment } & \multirow{2}{*}{$\begin{array}{l}\text { Date of } \\
\text { sowing }\end{array}$} & \multirow[t]{2}{*}{ SMW } & \multicolumn{7}{|c|}{ Per cent Disease Incidence (\%) } & \multirow{2}{*}{$\begin{array}{l}\text { Pods } \\
\text { per } \\
\text { plant }\end{array}$} & \multirow{2}{*}{$\begin{array}{c}\text { Yield } \\
\left(\begin{array}{c}\text { kg ha } \\
\text { 1) }\end{array}\right.\end{array}$} \\
\hline & & & 36 DAS & 43 DAS & 50 DAS & 57 DAS & 64 DAS & 71 DAS & 78 DAS & & \\
\hline T1 & $30 / 05 / 16$ & $22^{\text {nd }}$ & $\begin{array}{c}1.18 \\
(6.24)\end{array}$ & $\begin{array}{c}2.90 \\
(9.81)\end{array}$ & $\begin{array}{c}5.06 \\
(13.00)\end{array}$ & $\begin{array}{c}6.45 \\
(14.71)\end{array}$ & $\begin{array}{c}6.61 \\
(14.90)\end{array}$ & $\begin{array}{c}6.59 \\
(14.87)\end{array}$ & $\begin{array}{c}6.84 \\
(15.16)\end{array}$ & $\begin{array}{c}8.925 \\
(17.38)\end{array}$ & 1093.33 \\
\hline $\mathbf{T 2}$ & 06/06/16 & $23^{\text {rd }}$ & $\begin{array}{c}0.98 \\
(5.69)\end{array}$ & $\begin{array}{c}2.75 \\
(9.55)\end{array}$ & $\begin{array}{c}3.62 \\
(10.97)\end{array}$ & $\begin{array}{c}4.01 \\
(11.56)\end{array}$ & $\begin{array}{c}4.41 \\
(12.12)\end{array}$ & $\begin{array}{c}4.75 \\
(12.59)\end{array}$ & $\begin{array}{c}4.85 \\
(12.72)\end{array}$ & $\begin{array}{c}9.325 \\
(17.77)\end{array}$ & 1220.00 \\
\hline T3 & $13 / 06 / 16$ & $24^{\text {th }}$ & $\begin{array}{c}4.97 \\
(12.88)\end{array}$ & $\begin{array}{c}6.50 \\
(14.76)\end{array}$ & $\begin{array}{c}7.17 \\
(15.53)\end{array}$ & $\begin{array}{c}7.32 \\
(15.70)\end{array}$ & $\begin{array}{c}7.47 \\
(15.86)\end{array}$ & $\begin{array}{c}7.56 \\
(15.96)\end{array}$ & $\begin{array}{c}7.95 \\
(16.37)\end{array}$ & $\begin{array}{c}9.225 \\
(17.02)\end{array}$ & 634.00 \\
\hline $\mathrm{T4}$ & $20 / 06 / 16$ & $25^{\text {th }}$ & $\begin{array}{c}2.65 \\
(9.37)\end{array}$ & $\begin{array}{c}2.90 \\
(9.81)\end{array}$ & $\begin{array}{c}3.86 \\
(11.33)\end{array}$ & $\begin{array}{c}3.91 \\
(11.41)\end{array}$ & $\begin{array}{c}4.61 \\
(12.40)\end{array}$ & $\begin{array}{c}7.22 \\
(15.59)\end{array}$ & $\begin{array}{c}7.67 \\
(16.08)\end{array}$ & $\begin{array}{c}8.575 \\
(17.02)\end{array}$ & 718.66 \\
\hline $\mathrm{T5}$ & $27 / 06 / 16$ & $26^{\text {th }}$ & $\begin{array}{c}0.64 \\
(4.61)\end{array}$ & $\begin{array}{c}3.55 \\
(10.87)\end{array}$ & $\begin{array}{c}3.84 \\
(11.31)\end{array}$ & $\begin{array}{c}3.99 \\
(11.53)\end{array}$ & $\begin{array}{c}5.38 \\
(13.42)\end{array}$ & $\begin{array}{c}6.60 \\
(14.88)\end{array}$ & $\begin{array}{c}8.45 \\
(16.90)\end{array}$ & $\begin{array}{c}7.700 \\
(16.10)\end{array}$ & 336.00 \\
\hline T6 & $04 / 07 / 16$ & $27^{\text {th }}$ & $\begin{array}{c}4.68 \\
(12.50)\end{array}$ & $\begin{array}{c}5.32 \\
(13.33)\end{array}$ & $\begin{array}{c}5.77 \\
(13.89)\end{array}$ & $\begin{array}{c}8.35 \\
(16.79)\end{array}$ & $\begin{array}{c}9.77 \\
(18.21)\end{array}$ & $\begin{array}{c}10.81 \\
(19.19)\end{array}$ & $\begin{array}{c}13.60 \\
(21.64)\end{array}$ & $\begin{array}{c}6.200 \\
(14.41)\end{array}$ & 116.00 \\
\hline T7 & $11 / 07 / 16$ & $28^{\text {th }}$ & $\begin{array}{c}5.61 \\
(13.70)\end{array}$ & $\begin{array}{c}5.90 \\
(14.06)\end{array}$ & $\begin{array}{c}9.35 \\
(17.80)\end{array}$ & $\begin{array}{c}10.64 \\
(19.03)\end{array}$ & $\begin{array}{c}11.13 \\
(19.48)\end{array}$ & $\begin{array}{c}12.01 \\
(20.28)\end{array}$ & $\begin{array}{c}15.15 \\
(22.90)\end{array}$ & $\begin{array}{c}6.000 \\
(14.17)\end{array}$ & 112.00 \\
\hline & S.Em \pm & & 0.22 & 0.29 & 0.33 & 0.39 & 0.51 & 0.57 & 0.68 & 0.33 & \\
\hline & at $5 \%$ & & 0.68 & 0.88 & 1.02 & 1.21 & 1.58 & 1.75 & 2.09 & 1.01 & \\
\hline & $\mathrm{CV}$ & & 14.94 & 13.43 & 11.95 & 12.27 & 14.54 & 14.33 & 14.70 & 8.22 & \\
\hline
\end{tabular}

* DAS: Days After Sowing; SMW: Standard Meteorological Week 
Nay et al., (2008) reported minimum infection of MYMV when mungbean was sown in June, July, August and September. Maximum incidence was observed in Febraury, March and April sown crop in Yezin region of Myanmar, thereby indicating that drier period during the moths of February to June could help in whitefly build which was noticed in our surveillance study. Subsequent reduction in disease incidence was due to onset of rains detrimental to whitefly population. Rashid et al., (2013) reported that among January-15, Febraury-1, Febraury-15, March-1, March-15 and April-1 sown crops, March $1^{\text {st }}$ sown crop showed minimum disease incidence (13- $26 \%$ ) with higher yield (2131 kg ha-1). Mahalakshmi et al., (2014) studied the effect of date of sowing on incidence of MYMV in blackgram. Sowing was done from June to April at 15 days interval. Among these sowings, June, July and October sown plots showed lesser incidence of MYMV compared to other dates of sowing due to frequent rainfall during the kharif season. However, they noticed maximum disease incidence and whitefly population during summer crop which indicates positive correlation of maximum temperature with whitefly and MYMV incidence and supports our findings beyond doubt. Naveed et al., (2015) also studied effect of eight different dates of sowing (May $26^{\text {th }}$, June $2^{\text {nd }}$, June $9^{\text {th }}$, June $16^{\text {th }}$, June $23^{\text {rd }}$, June $30^{\text {th }}$, July $7^{\text {th }}$ and July $14^{\text {th }}$ ) on incidence of MYMV and lowest incidence with highest yield (1990 kg ha $\left.{ }^{-1}\right)$ was observed in June $2^{\text {nd }}$ sown crop. Highest incidence and lowest yield was observed in July $14^{\text {th }}$ sown crop. The findings of our study advocate June first week is most suitable date for sowing of mungbean, which will avoid incidence of MYMV with higher yield.

The experiment on effect of date of sowing on MYMV incidence conducted during kharif showed that, ideal date of sowing for mungbean is $6^{\text {th }}$ June $\left(23^{\text {rd }}\right.$ SMW), which had lowest MYMV incidence and highest seed yield. Date of sowing had direct impact on incidence of MYMV, the experimental results concludes that early sowing of mungbean can escape the disease incidence and delayed sowing leads to higher disease incidence with lower yields. Hence, sowing of greengram can be recommended during first week of June (kharif).

\section{References}

Asghar, M., Saleem, M.F. Ali, A. and Ishaq, R. A. F., 2006, Effect of sowing dates and planting patterns on growth and yield of mungbean. J. Agric. Res., 44: 139-146.

Borah, B. and Dasgupta, I., 2012, Begomovirus research in India: A critical appraisal and the way ahead. $J$. Biosci., 37 (4): 791-806.

Hull, R., 2004, Mathew's Plant Virology. Fourth Edition. Elsevier Publishers, India, pp.180-182.

Kang, B. C, Yeam, I. and Jahn M. M., 2005, Genetics of plant virus resistance. Annu Rev Phytopathol. 43: 581-621.

Mahalakshmi, S. M., Adinarayana, M., Reddy, S. A. and Rao, K. Y., 2014, Influence of sowing time on incidence of whiteflies and severity of yellow mosaic virus disease in blackgram. $J$. Res., 42 (3): 60-65.

Naveed, M., Shafiq, M. and Saeed, M., 2015, Planting date effects on the incidence of MYMV and its cultivars performance under rainfed conditions. $P l$. Knowl., 4 (1): 7-12.

Nay, N. O., Yee, M. and Thein, M. M., 2008, Determination of varietal resistance and effect of sowing time on severity of mungbean yellow mosaic disease. Proce. Seventh ann. Res., pp.347-364.

Rashid, M. H., Aktar, M. S. and Ismail, H., 2013, Effect of dates of sowing on 
incidence and severity of Mungbean yellow mosaic virus and cercospora leaf spot of mungbean. Int. J. of Adv. in Res. \& Tech., 2 (9): $96-104$.

Rathi, Y. P. S. and Vijai Veer Singh., 2005, Epidemiology and Management of Mungbean Yellow Mosaic Virus, A Yellow plague of kharif pulses in India. New Agriculturist, 16 (2): 165-168.

Sahay, G., Sharma, B. K., Gupta, H. S., Pathak, K. A. and Prasad, M. S., 1999, Biotic stresses of pulses in North Eastern Hill regions of India. Indian $J$. Hill Farm., 12(2): 8-16.
Sheteawi, S. A and Tawfik, 2007, Interaction effect of some biofertilizers and irrigation water regime on Munbean growth and yield. J. Applied Sci. Res., 3: 251-262.

Singh, D. P., 1991, Genetics and Breeding of Pulse Crops. Kalyani Publ, Ludhiana, India, Pp. 6-11.

Singh, V. P., Chhabra, A. and Kharb, R. P. S., 1988, Production and utilization of mungbean in India. In Proceedings of the Second International Symposium. 16-20. November. 1987 Bangkok, Thailand. AVRDC. Shanhua. Tainan. pp: 58.

\section{How to cite this article:}

Meghashree Meti and Mallikarjun Kenganal. 2018. Influence of Dates of Sowing on Incidence of Mungbean Yellow Mosaic Virus (MYMV) in Mungbean. Int.J.Curr.Microbiol.App.Sci. 7(09): 2362-2367. doi: https://doi.org/10.20546/ijcmas.2018.709.293 